
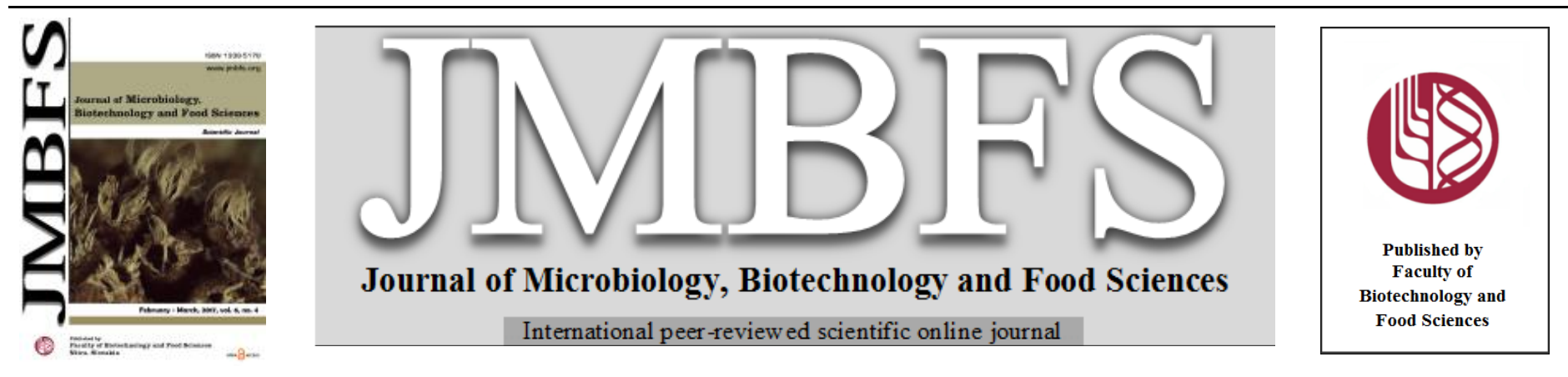

\title{
CURING EFFECTS ON THE GROWTH OF LISTERIA MONOCYTOGENES AND ESCHERICHIA COLI O157:H7 IN CAMEL MEAT USING MOST PROBABLE NUMBER-POLYMERASE CHAIN REACTION METHOD
}

\section{Hamid Reza Gheisari", Afshin Hamzeloo, Saeid Hosseinzadeh and Sara Basiri}

\section{Address(es):}

School of Veterinary Medicine, Departments of Food Hygiene, Shiraz University, Shiraz, 71345- 51731, Iran.

*Corresponding author: ghaisari@shirazu.ac.ir

doi: $10.15414 / j m b f s .2017 .6 .4 .1026-1029$

\section{ARTICLE INFO}

Received 2. 11. 2014

Revised 16.11.2016

Accepted 1. 12. 2016

Published 1. 2. 2017

Regular article

open $\partial$ access

\begin{abstract}
MPN-PCR method was used to determine Escherichia coli O157:H7 and Listeria monocytogenes in cured camel meat samples during nine days of storage. The MPN-PCR is based on the combination between the conventional Most Probable Number and the Polymerase Chain Reaction technique targeting the Stxland Stx2 gene for Ecoli O157:H7 and hlyA gene for L. monocytogenes. Growth of both bacteria in the cured and control experimental groups was initially subjected to a spectrophotometric MPN assay using a microplate reader followed by confirming by two PCR assays. It was shown that in the inoculated samples, the population of both microorganisms was significantly increased at all the test times. However, a significant reduction in the populations of both microorganisms was shown in the cured meat compared to the inoculated -but not- cured group. Our results suggested that curing can improve the microbial quality of camel meat.
\end{abstract}

Keywords: Listeria monocytogenes, Escherichia coli O157:H7, Curing, Camel meat

\section{INTRODUCTION}

One of the major concerns in the food industry is the preservation of meat and meat products (Drosinos et al., 2006). Highly perishable foods such as meat provide excellent conditions for the growth of hazardous microorganisms. Listeria monocytogenes and Escherichia coli $0157 \mathrm{H} 7$ are the most important food-borne pathogens of humans (Adzitey and Huda, 2010; Park et al., 1999). L. monocytogenes is a Gram-positive and ubiquitous bacterium responsible for foodborne disease (Listeriosis). The bacterium can contaminate several categories of foods. Multiplying at low temperatures makes L. monocytogenesa difficult pathogen to control in refrigerated foods that are consumed without further lethality treatments, such as reheating. (Delia and Silvia, 2009). E. coli O157:H7 is a foodborne pathogen with a low infectious dose that has been associated with meat and meat products (Sivapalasingam et al., 2004).The infection can lead to hemolytic uremic syndrome (HUS), characterized by hemolytic anemia, thrombocytopenia, and renal injury (Banatvala et al., 2001). The bacterium has the ability to survive at refrigeration temperatures (Perez Rodriguez et al., 2011). Several methods such as cooking, fermenting, drying and curing have been used to preserve meat. Curing is one of the oldest methods for preserving and protecting meat from spoilage. Meat curing is the application of salt, color fixing ingredients, and seasoning to inform unique properties to the product. Salt and nitrite are two main ingredients used to cure meat (Gheisari and Danesh, 2012).

Camel is one of the most popular domestic animals in the dry and semi dry regions (Knoess, 1977). Due to lower fat and cholesterol content and relatively higher polyunsaturated fatty acids, camel meat is healthier than beef (Kadimet al., 2008; Dawood and Alkanhal, 1995). Camel meat has a good capability for curing and additionally, mixed methods of curing resulted in more tender and higher quality than other methods (Gheisari and Danesh, 2012). There are no reports on the microbiological safety of the cured camel meat. Therefore, we determined the survival of E. coli O157:H7 and L. monocytogenes during the process of curing. Several methods have been employed to detect and enumerate the spoilage producing bacteria in foods. PCR is the most sensitive of rapid tests to detect microbial pathogens in samples (Yamamoto, 2002). In addition, the combination of MPN and PCR techniques (MPN-PCR procedure) is a rapid detection test with advantages of less work load and less material consumption (Chang et al., 2013).

\section{MATERIAL AND METHODS}

\section{Bacterial cultures}

A proven strain of $L$. monocytogenes (ATCC 19115) and nalidixic acid-resistant strain of E. coli O157:H7 (ATCC 43895) were provided by Department of Microbiology, School of Veterinary Medicine, Shiraz University. To confirm nalidixic acid-resistant E. coli $O 157: H 7$, the bacteria was cultred onto the McConkey agar (MERK, Germany) plate containing 400 $\mathrm{g} \mathrm{ml}^{-1}$ nalidixic acid and incubated at $37^{\circ} \mathrm{C}$ for $24 \mathrm{~h}$. Appearance of a colony was considered as bacterial resistance.

\section{Growth curve of bacteria}

L. monocytogenes and E. coli O157:H7 were cultured in Tripticase Soy Broth (TSB) (Merck, Germany) and incubated at $37^{\circ} \mathrm{C}$ for $24 \mathrm{~h}$. Bacterial suspension were then centrifuged at $3000 \mathrm{~g}$ for 5 minutes. $10 \mathrm{ml}$ of sterilized peptone water was added to the sediment. The process was repeated twice. Finally, $10 \mathrm{ml}$ of TSB was added to the sediment, serial decimal dilutions $\left(10^{-1}, 10^{-2}, 10^{-3}, 10^{-4}\right.$ and $10^{-5}$ ) were prepared and the absorbance of each dilution was measured by spectrophotometer (JENWAY, U.K). $100 \mu \mathrm{L}$ of each dilution was subsequently cultured to TSA medium and incubated at $37^{\circ} \mathrm{C}$ for $24 \mathrm{~h}$. Number of colonies was then recorded. Bacterial growth curve was plotted based on the absorbance and number of colonies for each concentration.

\section{Sampling procedure}

Six male, adult Iranian dromedary (one-humped camel), were slaughtered at local slaughterhouse. In order to complete the rigor mortis, the carcasses were stored refrigerated for $24 \mathrm{~h}$. The Longissimus dorsi muscles were dissected and trimmed off external fat and connective tissue. After that, meats were chopped into pieces about $1 \mathrm{~cm}$. In order to evaluate each of the bacterium, camel meat samples were divided into the following experimental groups:

Group 1: No treated samples (Negative Control).

Group 2: No curing meat containing the bacteria (E.coli O157:H7and/or $L$. monocytogenes) (Positive Control).

Group 3: Cured meat containing the bacteria (E. coli O157:H7and/or $L$. monocytogenes).

All treatments were performed in triplicate. 


\section{Meat curing}

Two kilograms of meats were mixed with curing compounds [ $\mathrm{NaCl}(22 \mathrm{~g})$ sodium nitrite $(0.18 \mathrm{~g})$, soy protein isolate $(15 \mathrm{~g})$, starch $(50 \mathrm{~g})$, spices $(15 \mathrm{~g})$, phosphate $(26 \mathrm{~g})$, water and ice $(400 \mathrm{~g})$ and ascorbic acid $(0.2 \mathrm{~g})$ for $1 \mathrm{~kg}$ meat $]$ before being stored at $4{ }^{\circ} \mathrm{C}$ for 9 days. Microbial count was recorded at the days $1,3,5$ and 9 . All the experiments were performed in triplicate.

\section{Inoculation of the bacteria}

Each bacterium was inoculated in TSB medium and following a $24 \mathrm{~h}$ incubation at $37^{\circ} \mathrm{C}$, the number of colonies were determined according to the growth curve of bacteria. After that, $10^{4} \mathrm{cfu} / \mathrm{g}$ of each bacterium was added to the meat samples (Groups 2 and 3) and mixed well.

\section{Bacterial counting using MPN-method}

Different experimental groups (containing bacteria) were homogenized to prepare a 10-fold serial dilutions using peptone water up to 10-5. 96-well microplates were used for MPN test. For detection and enumeration of $E$-coli $\mathrm{O} 157: \mathrm{H} 7$ and $L$. monocytogenes, double-strength McConkey broth contained nalidixic acid and Buffered Listeria Enrichment Broth (BLEB) were respectively used. $100 \mu \mathrm{L}$ of each dilution of the homogenate was transferred into culture wells containing $100 \mu \mathrm{L}$ of growth medium.

For each sample, 3 replicate MPN assays were set up for each dilution step, and the microplates were incubated in the $37^{\circ} \mathrm{C}$ for $24 \mathrm{~h}$. After incubation, the turbid wells (L. monocytogenes) and/or yellow discoloration (E-coli O157:H7) were considered as positive. The pattern of growth was then read from the MPN table to provide the most probable number and $95 \%$ confidence interval.To confirm the MPN results, each positive MPN well was used for the surface plating on the selective agar medium. Palcam agar (Merck, Germany) and CTS-Mac (AQUALAB, Germany) were respectively used for the isolation of L.monocytogenes and E-coli O157:H7. Cultured plates were incubated at $37^{\circ} \mathrm{C}$ for $24 \mathrm{~h}$. The positive MPN results were then subjected to PCR for the detection of Stxland Stx2 genes specific for E. coli O157:H7 and hlyA gene for $L$. monocytogenes.

\section{PCR}

\section{DNA extraction}

On days $0,2,4$ and $8,200 \mu \mathrm{L}$ of turbid broth, were stored at $-20^{\circ} \mathrm{C}$ for further use DNA extraction was carried out using the boiled-cell method as was previously described (Chai et al., 2007), with some modification. Briefly, the samples were thawed and centrifuged at $10000 \mathrm{rpm}$ for 10 minutes. The supernatant was discarded; the pellet was re-suspended with $50 \mu \mathrm{L}$ of deionized water, vortexed and boiled in a water bath $\left(100{ }^{\circ} \mathrm{C}\right)$ for 10 minutes to lyses the cells followed by cooled on ice for 2 minutes. Samples were then centrifuged at $10,000 \mathrm{rpm}$ for 10 minutes. Aliquot of the supenatant which contained the template DNA was transferred to a sterile tube and stored at $-20^{\circ} \mathrm{C}$ until further use.

\section{MPN-PCR for Listeria monocytogenes}

One pair of primers $F$ and $R$ with sequence of 5' CGGAGGTTCCGCAAAAGATG-3' and 5'- CCTCCAGAGTGATCGATGTT-3' was designed to amplify hlyA gene at $485 \mathrm{bp}$ region. $\mathrm{PCR}$ reaction was carried out in $25 \mathrm{ml}$ reaction mixture consisting $2.5 \mu \mathrm{L}$ PCR buffer, $1.5 \mu \mathrm{L} \mathrm{MgCl}_{2}, 0.5 \mu \mathrm{L}$ dNTPs mix, $0.5 \mu \mathrm{L}$ TaqPolymerase (PROMEGA, USA), $0.5 \mu \mathrm{L}$ of each primer, $1.5 \mu \mathrm{L}$ DNA templates and $17.5 \mu \mathrm{L}$ sterile distilled water. Amplification of DNA segment was performed in thermal cycler (APPLIED BIOSYSTEMS, USA) using thethermo-cycling conditions of initial denaturation $\left(94^{\circ} \mathrm{C}\right.$ for 2 minutes),
35 cycles of denaturation $\left(94^{\circ} \mathrm{C}\right.$ for 45 seconds), annealing $\left(64^{\circ} \mathrm{C}\right.$ for 45 seconds), extension $\left(72^{\circ} \mathrm{C}\right.$ for 1 minute $)$ followed by final extension $\left(72^{\circ} \mathrm{C}\right.$ for 5 minutes $)$ PCR products were loaded in $1.5 \%$ agarose gel stained with ethidium bromide (1mg. $\mathrm{ml}^{-1}$ ) and were electrophoresis at $50 \mathrm{~mA}$ for one hour. Gel was visualized under UV light using and photograph (SYNGENE, USA).

\section{MPN-PCR for E. coli O157:H7}

Two pairs of primers used in MPN-PCR were Stx1 and Stx2 primer. Sequences of primers used are shown in table 1. PCR reaction was carried out in $21.5 \mathrm{ml}$ reaction mixture consisting $2.5 \mu \mathrm{L}$ PCR buffer, $1.25 \mu \mathrm{L} \mathrm{MgCl}_{2}, 1 \mu \mathrm{L}$ dNTPs mix, $0.5 \mu \mathrm{L}$ TaqPolymerase (Promega, USA), $0.5 \mu \mathrm{L}$ of each primer, $1.5 \mu \mathrm{L}$ DNA templates and $13.75 \mu \mathrm{L}$ sterile distilled water. Amplification of DNA segment was performed in thermal cycler using the thermo-cycling conditions of initia denaturation $\left(94{ }^{\circ} \mathrm{C}\right.$ for 2 minutes), 35 cycles of denaturation $\left(95{ }^{\circ} \mathrm{C}\right.$ for 60 seconds), annealing $\left(64{ }^{\circ} \mathrm{C}\right.$ for 60 seconds), and extension $\left(72^{\circ} \mathrm{C}\right.$ for 90 seconds $)$ followed by final extension $\left(72^{\circ} \mathrm{C}\right.$ for 7 minutes). PCR products were analyzed on gels of $1.2 \%$ agarose.

Table 1 Sequence and size of primers based on the coding from the following genes used for E. Coli $\mathrm{O} 157 \mathrm{H} 7$

\begin{tabular}{|c|c|c|c|}
\hline Primer name & Gene & Oligonucleotide sequence (5'-3') & $\begin{array}{l}\text { Amplicon } \\
\text { size (bp) }\end{array}$ \\
\hline$S t x_{l} \mathrm{~F}$ & $S t x_{1}$ & ATAAATCGCCATTCGTTGACTAC & \multirow{2}{*}{480} \\
\hline $\operatorname{Stx}_{l} \mathrm{R}$ & Stx $_{1}$ & AGAACGCCCACTGAGATCATC & \\
\hline $\operatorname{Stx}_{2} \mathrm{~F}$ & $S_{t x_{2}}$ & GGCACTGTCTGAAACTGCTCC & \multirow{2}{*}{510} \\
\hline $\operatorname{Stx}_{2} \mathrm{R}$ & $\mathrm{Stx}_{2}$ & TCGCCAGTTATCTGACATTCTG & \\
\hline
\end{tabular}

\section{Statistical analysis}

The data were analyzed using the Repeated Measure ANOVA test of SAS 9/1 statistical software. Duncan's post hoc test was used to assess differences between groups. Differences were considered significant at values of $\mathrm{P}<0.05$.

\section{RESULTS AND DISCUSSION}

Moisture, protein, fat and ash percents of camel meat samples were $73.82 \pm 2.63$ $23.57 \pm 0.64,4.16 \pm 0.72,1.22 \pm 0.35$, respectively. Microbial contamination can reduce the quality of fresh meat, shorten its shelf- life and cause economic losses and health hazards. Minimizing product contamination and delaying or inhibiting growth of spoilage and pathogenic organisms in the product are major keys for improving fresh meat shelf life and increasing consumer safety. While general cleanliness and proper sanitation are very effective, other means of controlling microbial growth in the meat products may be proven useful.The contamination of camel meat with E. coli $\mathrm{O} 157: \mathrm{H} 7$ and L. monocytogenes was detected by using a combination of culture method and MPN-PCR technique. E. coli O157:H7 was revealed as clear colony occasionally with yellow-orange halo on CTS-Mac agar and L. monocytogenes exhibited as gray-green colony with black halo on PALCAM agar. Results of the bacterial count by MPN method are shown in tables 2 and 3. Even though, an initial contamination to L. monocytogenes was obvious in our samples as shown in table 3, the curing was effective enough to significantly reduce the microorganisms in all the experimental groups.

Both microorganisms in all the experimental groups (except for E.coli O157:H7) increased during the storage time but the curing was dramatically reduced the number of them. All of the turbid samples in Buffered Listeria Enrichment Broth were shown a DNA fragment of the expected size (485bp) for Listeria spp Positive samples in MPN test for E. coli $\mathrm{O} 157: \mathrm{H} 7$ produced a DNA band at 480 and $510 \mathrm{bp}$ regions (figure 1).

Table 2 Details of the MPN values for E. coli $\mathrm{O}_{157}-\mathrm{H}_{7}(\mathrm{cfu} / \mathrm{g})$ during 9 days of storage at $4{ }^{\circ} \mathrm{C}$.

\begin{tabular}{lllll}
\hline Group & \multicolumn{4}{c}{ Days of storage } \\
\cline { 2 - 5 } & 1 & 3 & 9 \\
\hline Group 1 & $0 \pm 0^{\mathrm{a}}$ & $0 \pm 0^{\mathrm{a}}$ & $0 \pm 0^{\mathrm{a}}$ & $0 \pm 0^{\mathrm{a}}$ \\
Group 2 & $833.5 \pm 201.64^{\mathrm{cA}}$ & $5143 \pm 1197.18^{\mathrm{cB}}$ & $42475 \pm 9933.06^{\mathrm{cC}}$ & $110000 \pm 12306.38^{\mathrm{cD}}$ \\
Group 3 & $317.5 \pm 62.99^{\mathrm{bA}}$ & $445 \pm 17.32^{\mathrm{bB}}$ & $670 \pm 115.38^{\mathrm{bC}}$ & $3300 \pm 471.31^{\mathrm{bD}}$ \\
\hline
\end{tabular}


Table 3 MPN results of L. monocytogenes (cfu/g) during 9 days of storage at $4{ }^{\circ} \mathrm{C}$.

\begin{tabular}{lllll}
\hline Group & \multicolumn{4}{c}{ Days of storage } \\
\cline { 2 - 5 } & 1 & 3 & 5 & 9 \\
\hline Group 1 & $240 \pm 11.54^{\mathrm{bA}}$ & $2375 \pm 50^{\mathrm{cB}}$ & $59350 \pm 11981.63^{\mathrm{cC}}$ & $40500 \pm 4489.80^{\mathrm{cC}}$ \\
Group 2 & $555.75 \pm 133.53^{\mathrm{CA}}$ & $1582.5 \pm 248.01^{\mathrm{bB}}$ & $4100 \pm 707.55^{\mathrm{bC}}$ & $19950 \pm 4015.67^{\mathrm{bD}}$ \\
Group 3 & $33 \pm 4.71^{\mathrm{aA}}$ & $45.5 \pm 13.48^{\mathrm{aA}}$ & $23 \pm 9.76^{\mathrm{aA}}$ & $189 \pm 37.95^{\mathrm{aB}}$ \\
\hline
\end{tabular}

Values are mean \pm standard deviation. Group 1: control; Group 2: No curing meat containing the bacteria; Group 3: Cured meat containing the bacteria. The different small letters in the same column indicate significant differences between groups and different large letters in the same row indicates significant differences between the experimental days $(\mathrm{P}<0.05)$.

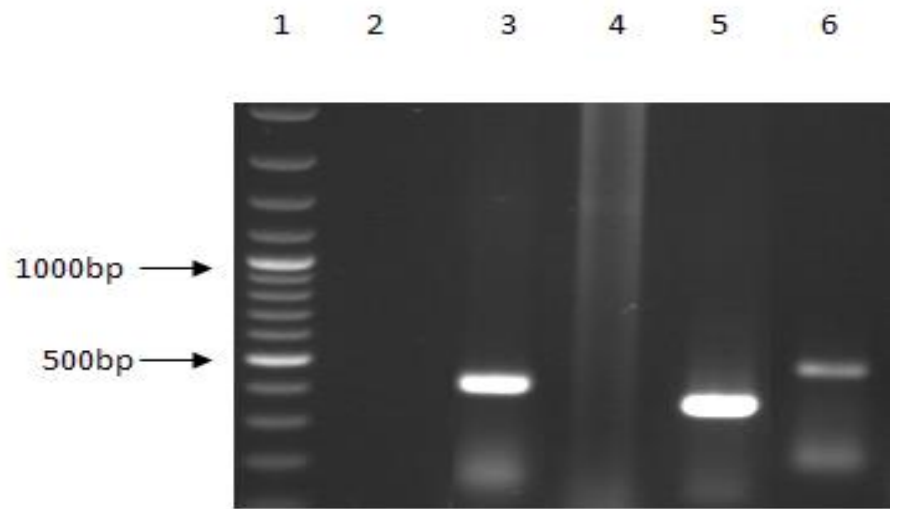

Figure 1 A representing 1.5\% agarose gel electrophoresis. Lane 1: 100 bp DNA ladder; Lane 2: negative control (no template); Lane 3: 485 bp fragment corresponding to the hly gene of L. monocytogenesis; Lane 4: negative sample; Lane $5 \& 6480 \mathrm{bp}$ and $510 \mathrm{bp}$ fragments corresponding to the Stx1 and Stx2 genes of $E$. coli $\mathrm{O} 157: \mathrm{H} 7$

Al-Bachir and Zeinoun (2009) finde $10^{6} \mathrm{CFU} / \mathrm{g}$ total (mesophilic aerobic) plate count and $10^{3} \mathrm{CFU} / \mathrm{g}$ coliform count in the camel meat on day 0 . This microbial load was high enough to indicate that the meat had been heavily contaminated during slaughtering and fabrication operations or alternatively, that the meat had been stored for an unknown length of time before being purchased for the study. Except for E. coli $\mathrm{O} 157 \mathrm{H} 7$ in the negative control group, the bacterial populations were increased during 9 days of storage at $4{ }^{\circ} \mathrm{C}$. The MPN method is the most advantageous to detect lower levels of microorganisms in food samples (10-100 MPN/g) (Martin et al., 2004). Recently, the MPN-PCR method is widely used for detection and enumeration of food-borne pathogens in various foods (Chai et al., 2007; Lee et al., 2009). It was also noticeable that this method is more useful and effective for detecting microorganisms such as $L$. monocytogenes and E-coli $\mathrm{O} 157: \mathrm{H} 7$ than the plating method. Thus, application of the MPN-PCR method in the present study suggest for more accurate and reliable results. Recently, more attention is paid to the nutritional value of the camel meat (Ulmer et al., 2004). The three most common methods use for camel meat preservation and processing are thermal processing, smoking and curing (Kalalouet al., 2004; Zegeye, 1999).

Salt has a variety of effects on both food tissues and microbial cells which are responsible for its preservation action such as interactive enzyme systems vital to the cells, stopping or slowing the growth and drawing water out the cells due to osmotic pressure. Sodium chloride $(\mathrm{NaCl})$ has been traditionally used in curing processes. One of the functions of $\mathrm{NaCl}$ in meat products is to extract myofibrillar proteins. Extraction and solubilization of these muscle proteins contributes to meat particle binding, fat emulsification, and water-holding capacity, and thus, it reduces cook losses and improves quality and texture (Sofos, 1986). The role of nitrite in cured meat is four-fold: i) providing the characteristic pink-red cured-meat color to the lean tissue; ii) inhibiting the growth of a number of bacteria that cause food poisoning or spoilage; iii) contributing to the distinctive flavour of cured meats; and iv) retarding the oxidative rancidity in processed meat products, principally through a process of metal chelation (Honikel, 2008). Results of this study showed that curing may significantly reduce the growth of L. monocytogenes and E. Coli O157: H7 in camel meat. From the first day, number of the bacteria in the treated group was less than the controls. Low $\mathrm{pH}$ is an important factor contributing to the inhibition growth of foodborne pathogens. Several factors including $\mathrm{pH}$ associate with the survival of E. coli and L.monocytogenes during fermentation of sausage (Cho et al., 2011). Gheisari and Danesh (2012) report that curing of camel meat will reduce $\mathrm{pH}$ values of meat. We hypothesize that change in $\mathrm{pH}$ contributed to the reduction of E. coli and Listeria populations during the curing of camel meat. Additionally, in a work conducted by Castano et al. (2002) the counts of Enterobacteriaceae in the sausages manufactured industrially decrease continuously from the second day after the sausage mass is stuffed.This decrease is probably due to the addition of curing salt to the samples. Kajak and Kolożyn-Krajewska (2006) reported that the addition of $60 \mathrm{ppm}$ sodium nitrite to meat was significantly inhibited the growing of microorganisms. While $\mathbf{Y u}$ and Chou (1997) reported that sodium nitrite at the concentrations between 0.07 and $0.15 \mathrm{~g} \mathrm{~kg}-1$ have no significant effect on the reduction of $E$ coli O157: $\mathrm{H} 7 \mathrm{in}$ sausage. Camel meat is a potential source of meat particularly in the arid tropics. As we found here, curing was considerably reduced the risk of microbial contamination.

\section{CONCLUSION}

Camel meat is a potential source of meat particularly in the arid tropics. If it was cured, it would be less susceptible to the microbial contamination. However, more research work in the areas of meat production, technology, marketing, and social awareness is needed to exploit the potential of camels as a source of meat and related products.

Acknowledgments: This work was kindly supported by Shiraz University, School of Veterinary Medicine, Shiraz, Iran.

\section{REFERENCES}

ADZITEY, F., Huda, N. 2010. Listeria monocytogenes in foods: Incidences and possible control measures. African Journal of Microbiology Research, 4(25), 2848-2855.

Al-ANI, F.K. 2004. Use and production of camels. In F. K. Al-Ani (Ed.). Camel management and diseases (pp. 91-114). (1st ed.). : Al-Sharq Printing Press.

Al-BACHIR, M., ZEINOUN, R. 2009. Effect of gamma irradiation on microbial load and quality characteristics of minced camel meat. Meat Science, 82, 119124.http://dx.doi.org/10.1016/j.meatsci.2008.12.012.

BANATVALA, N., GRIFFIN, P.M., GREENE, K.D., BARRETT, T.J., BIBB W.F., GREEN, J.H., et al. 2001. The United States National Prospective Hemolytic Uremic Syndrome Study: microbiologic, serologic, clinical, and epidemiologic findings. Journal of Infectious Disease, 183, 1063 70.http://dx.doi.org/10.1086/319269.

CASTANO, A., GARCIA FONTIAN, M.C., FRESNO, J.M., TORNADIJO, M.E., CARBALLO, J. 2002. Survival of Enterobacteriaceae during processing of Chorizo de cebolla, a Spanish fermented sausage. Food Control,13, 107-115. http://dx.doi.org/10.1016/S0956-7135(01)00089-5.

CHAI, L. C., TUNUNG, R., USHA, M. R., JURIN, W. G., Fatimah, A. B. Farinazleen, M. G., et al. 2007. Thermophilic Campylobacter spp. in salad vegetables in Malaysia. International Journal of Food Microbiology, 117, 106 111. http://dx.doi.org/10.1016/j.jijfoodmicro.2007.02.014.

CHANG, W.S., AFSAH-HEJRI, L., RUKAYADI, Y., KHATIB, A., LYE, Y. L., LOO, Y. Y., MOHD SHAHRIL, N., PUSPANADAN, S., KUAN, C.H., GOH, S.G., JOHN, Y.H.T., NAKAGUCHI, Y., NISHIBUCHI, M. SON, R. 2013 Quantification of Escherichia coli O157:H7 in organic vegetables and chickens. International Food Research Journal, 20(2), 1023-1029.

CHO, G-Y., LEE, M.H., CHOI, C. 2011. Survival of Escherichia coliO157:H7 and Listeria monocytogenes during kimchi fermentation supplemented with raw $\begin{array}{llll}\text { pork meat. Food Control, 22, } 1253- & \end{array}$ http://dx.doi.org/0.1016/j.foodcont.2011.01.026.

DAWOOD, A., ALKANHAL, M.A. 1995. Nutrient composition of Najdi- Camel Meat. Meat Science, 39, 71-78.

http://dx.doi.org/10.1016/0309-1740(95)80008-5.

DELIA, c., SILVIA, B. 2009. Parma ham: a low risk-food for human transmission of Listeria monocytogenes. Annali della Facoltà di Medicina Veterinaria, Università di Parma, 29, 39 - 50.

DROSINOS, E.H., MATARAGAS, M., KAMPANI, A., KRITIKOS, D., METAXOPOULOS, I. 2006. Inhibitory efect of organic acid salts on spoilage flora in culture medium and cured cooked meat products under commercial manufacturing conditions. Meat Science, 73, 75-81. http://dx.doi.org/10.1016/j.meatsci.2005.11.003.

GHEISARI, H.R., DANESH, S. 2012. Biochemical and functional properties of cured camel meat by dry, wet and mixed mthods. Online Journal of Veterinary Research, 16 (4), 204-214.

HONIKEL, K.O. 2008. The use and control of nitrate and nitrite for the processing of meat products. Meat Science, 78 (1-2), 68-76. http://dx.doi.org/10.1016/j.meaysci.2007.05.030. 
KADIM, I. T., MAHGOUB, O., PURCHAS, R. W. 2008. A review of the growth, and of the carcass and meat quality characteristics of the one-humped camel (Camelus dromedaries). Meat Science, 80, 555-569. http://dx.doi.org/10.1016/j.meatsci.2008.02.010.

KALALOU, I., FAID, M., AHAMI, T.A. 2004. Improving the quality of fermented camel sausage by controlling undesirable microorganisms with selected lactic acid bacteria. International Journal of Agriculture and Biology, 3, 447-451.

KAJAK, K., KOLOZYN-KRAJEWSKA, D. 2006. Construction of predictive models of growth of microorganisms in salted and cured meat products. Innovative Food Science and EmergingTechnologies, 7, 152-159. http://dx.doi.org/10.1016/j.ifset.2005.09.003

KNOSESS, K. H. 1977. The camel as a meat and milk animal. World Animal Review, 22, 3-8.

LEE, H. Y., CHAI, L. C., TANG, S. Y., SELAMAT, P., FARINAZLEEN, M. G., YOSHITSUGU, N., et al. 2009. Short communication: application of MPNPCR in biosafety of Bacillus cereus for ready-to-eat cereals. Food Control, 20, 1068- 1071. http://dx.doi.org/10.1016/j.foodcont.2009.01.009.

MARTIN, B., JOFRE, A., GARRIGA, M., HUGAS, M., AYMERICH, T. 2004 Quantification of Listeria monocytogenes in fermented sausages by MPN-PCR method. Letters in Applied Microbiology, 39, 290- 295 http://dx.doi.org/10.1111/j.1472-765X.2004.01580.x.

PARK, S., WOROBO, R.W., RICHARD A. DURST, R.A. 1999. Escherichia coli $\mathrm{O} 157: \mathrm{H} 7$ as an Emerging Foodborne Pathogen: A Literature Review. Critical Reviews in Food Science and Nutrition, 39(6), 481-502. http://dx.doi.org/10.1080/20013891081674.

PEREZ RODRIGUEZ, F., CAMPOS, D., RYSER, E. T., BUCHHOLZ, A. L. POSADA-IZQUIERDO, G. D. MARKS, B. P. 2011. A mathematical risk model for Escherichia coli $\mathrm{O} 157: \mathrm{H} 7$ cross-contamination of lettuce during processing Food Microbiology, 28, 694-701. http://dx.doi.org/10.1016/i.fm.2010.06.008. SIVAPALASINGAM, S., FRIEDMAN, C.R., COHEN, L., TAUXE, R.V. 2004 Fresh produce: a growing cause of outbreaks of foodborne illness in the United States, 1973 through 1997. Journal of Food Protection,67, 2342-2353. PMID: 15508656

SOFOS, N.J. 1986. Use of phosphates in low-sodium meat products. Food Technology, 40(9), 53-63.

ULMER, K., HERRAMANN, K., FISCHER, A. 2004. Meat products from camel meat. In: Milk and Meat from the Camel. (Farah, Z., A. Fischer, Eds.), Vdf Hochschulverlag AG an der ETH Zurich, ETH Zentrum, CH-8092 Zurich, 137 228. ISBN $372812527 \mathrm{X}$

YAMATO, Y. 2002. PCR in Diagnosis of Infection: Detection of Bacteria in Cerebrospinal Fluids. Clinical and Diagnostic Laboratory Immunology, 508-514. http://dx.doi.org/10.1128/CDLI.9.3.508-514.2002.

YU, C-F., CHOU, C-C. 1997. Fate of Escherichia coli O157: H7 in Chinesestyle sausage during the drying step of the manufacturing process as affected by the drying condition and curing agent. Journal of Science Food Agriculture, 74 551- 556. http://dx.doi.org/10.1002/(SICI)1097-0010(199708)74:4<551::AIDJSFA835> 3.0.CO;2-0

ZEGEYE, A. 1999: A note on the influence of heat treatment, salting and smoking on the acceptability of camel products. Meat Science, 53, 217-219. http://dx.doi.org/10.1016/S0309-1740(99)00057-1. 